\section{Carbon Footprint and Variable Costs of Production Components for a Container-grown Evergreen Shrub Using Life Cycle Assessment: An East Coast U.S. Model}

\author{
Dewayne L. Ingram ${ }^{1,4}$ \\ Department of Horticulture, N-318 Agricultural Sciences Center, University \\ of Kentucky, Lexington, KY 40546-0091
}

Charles R. Hall ${ }^{2}$

Department of Horticultural Sciences, Texas A\&M University, 2133 TAMU, College Station, TX 77843-2133

\author{
Joshua Knight ${ }^{3}$ \\ Department of Horticulture, $N$-318 Agricultural Sciences Center, University \\ of Kentucky, Lexington, KY 40546-0091
}

Additional index words. global warming potential, greenhouse gas emission, carbon sequestration, nursery crops, landscape horticulture

\begin{abstract}
The production components of an evergreen shrub (Ilex crenata 'Bennett's Compacta') grown in a no. 3 container in an east coast U.S. nursery were analyzed for their costs and contributions to carbon footprint, as well as the product impact in the landscape throughout its life cycle. A life cycle inventory was conducted of input materials, equipment use, and all cultural practices and other processes used in a model production system for this evergreen shrub. A life cycle assessment (LCA) of the model numerated the associated greenhouse gas emissions (GHG), carbon footprint, and variable cost of each component. The LCA also included the transportation and transplanting of the final product in the landscape as well as its removal after a 40-year useful life. GHG from input products and processes during the production (cutting-to-gate) of the evergreen shrub were estimated to be $2.918 \mathrm{~kg} \mathrm{CO}_{2} \mathrm{e}$. When considering carbon sequestration during production weighted over a 100-year assessment period, the carbon footprint for this model system at the nursery gate was $2.144 \mathrm{~kg} \mathrm{CO}_{2} \mathrm{e}$. Operations, combining the impact of material and equipment use, that contributed most of GHG during production included fertilization $\left(0.707 \mathrm{~kg} \mathrm{CO} \mathrm{CO}_{2} \mathrm{e}\right)$, the liner and transplanting $(0.461 \mathrm{~kg}$ $\left.\mathrm{CO}_{2} \mathrm{e}\right)$, the container $\left(0.468 \mathrm{~kg} \mathrm{CO}_{2} \mathrm{e}\right)$, gravel and ground cloth installation $\left(0.222 \mathrm{~kg} \mathrm{CO}_{2} \mathrm{e}\right)$, substrate materials and preparation $\left(0.227 \mathrm{~kg} \mathrm{CO}_{2} \mathrm{e}\right)$, and weed control $\left(0.122 \mathrm{~kg} \mathrm{CO}_{2} \mathrm{e}\right)$. The major contributors to global warming potential (GWP) were also major contributors to the cutting-to-gate variable costs $\mathbf{( \$ 3 . 2 2 4 )}$ except for processes that required significant labor investments. Transporting the shrub to the landscaper, transporting it to the landscape site, and transplanting it would result in GHG of $0.376,0.458$, and $0 \mathrm{~kg} \mathrm{CO} 2$, respectively. Variable costs for postharvest activities were $\$ 6.409$ and were dominated by labor costs $(90 \%)$.
\end{abstract}

Producers of landscape plants are increasingly incorporating sustainable production practices to influence social acceptance of those plants in terms of their environmental, economic, and health and well-being features.

Received for publication 10 May 2016. Accepted for publication 21 June 2016.

This material is based on work that is supported by the National Institute of Food and Agriculture, U.S. Department of Agriculture, Specialty Crop Research Initiative, under award number 2014-51181-22372. We thank Jim Owen, Department of Horticulture, Virginia Tech, for the assistance.

${ }^{1}$ Professor.

${ }^{2}$ Professor and Ellison Chair in International Floriculture.

${ }^{3}$ Extension Associate for Horticulture.

${ }^{4}$ Corresponding author. E-mail: dingram@uky.edu. et al., 2006; Hayashi et al., 2006; Koerber et al., 2009; Liebig et al., 2008; Payraudeau and van der Werf, 2005) including landscape plant production (Beccaro et al., 2014; Ingram 2012). LCA has been used to describe environmental impacts of the nursery industry in the Piemonte region (Beccaro et al., 2014) and the Pistoia plant production district (Lazzerini et al., 2016; Nicese and Lazzerini, 2013) of Italy on an area basis. The carbon footprint of a product or activity is a measure of the associated GHG and expressed as the GWP of those gases. The GWP for the production and distribution of trees in nos. 5 and 9 containers in the United States was reported by Kendall and McPherson (2012) as 4.6 and $15.3 \mathrm{~kg} \mathrm{CO}_{2} \mathrm{e}$, respectively. Ingram and Hall (2015a) conducted a LCA of a potin-pot production system of a red maple in a no. 25 container and reported GHG of $15.317 \mathrm{~kg} \mathrm{CO}_{2} \mathrm{e}$ and a cutting-to-gate GWP of $10.742 \mathrm{~kg} \mathrm{CO} \mathrm{CO}_{2} \mathrm{e}$. Some of these published studies have focused on the details of operational protocols and their impact on GWP, or the products' carbon footprint. The propagation-to-landscape GWP for fieldgrown, 5-cm-caliper Acer rubrum L. (red maple), Picea pungens Engelm (colorado blue spruce), and Cercis canadensis L. (redbud) and 0.9-m Judd viburnum (Viburnum $\times j u d d i$ Rehder) and a 0.6-m 'Densiformis' yew (Taxus $\times$ media Rehder) shrubs were reported as 20.9 (adjusted for more inclusive fuel and weighted sequestration during production), 13.6, 13.7, 3.16, and $3.22 \mathrm{~kg} \mathrm{CO}_{2} \mathrm{e}$, respectively (Hall and Ingram, 2015; Ingram, 2012, 2013; Ingram and Hall, 2013, 2014a, $2014 b, 2015 a)$. These studies have also estimated carbon sequestration from the atmosphere during the life of the plant, weighted over a 100-year assessment period. Protocols for shrub production in containers are significantly different from field production systems and production of trees in larger containers. The objective of this study was to determine the GHG and variable costs of production system components for an evergreen shrub in a no. 3 container on the east coast of the United States.

\section{Methods}

Within a maturing industry, the economic portion of the triple bottom line is important (Hall, 2010) and the nursery industry has traditionally sought ways to minimize environmental impact of production. Social sustainability is reflected in the purchasing decisions made by end consumers. Understanding the environmental impacts of production system protocols could allow managers to increase efficiency and reduce potentially negative impacts of more sustainable systems. Understanding the ecosystem services of landscape plants could provide information to more effectively market these products to environmentally conscious consumers (Ingram and Hall, 2015b; Yue et al., 2011).

LCA has been used to characterize agricultural and bioenergy production systems (Davis et al., 2009; Debolt et al., 2009; Farrell

\section{Goal, scope, and functional unit}

The functional unit for this LCA study was an evergreen shrub, such as Ilex crenata 'Bennett's Compacta', in a no. 3 container on the mid-Atlantic coast of the United States. A life cycle inventory for the model production system was based on interviews with nursery managers in the region and guided by published best management practices (Southern Nursery Association, 2013) (Fig. 1). The boundaries for this model assumed cuttings would be taken from current nursery stock in February and stuck 2 cuttings per 8-cm cell in a flat and placed in a Quonset greenhouse with bottom heat. The liner would be transplanted to a no. 3 container in September or October and grown for 24 months on an outdoor gravel bed covered with a ground cloth. Finished plants would be transported by tractor-trailer to 


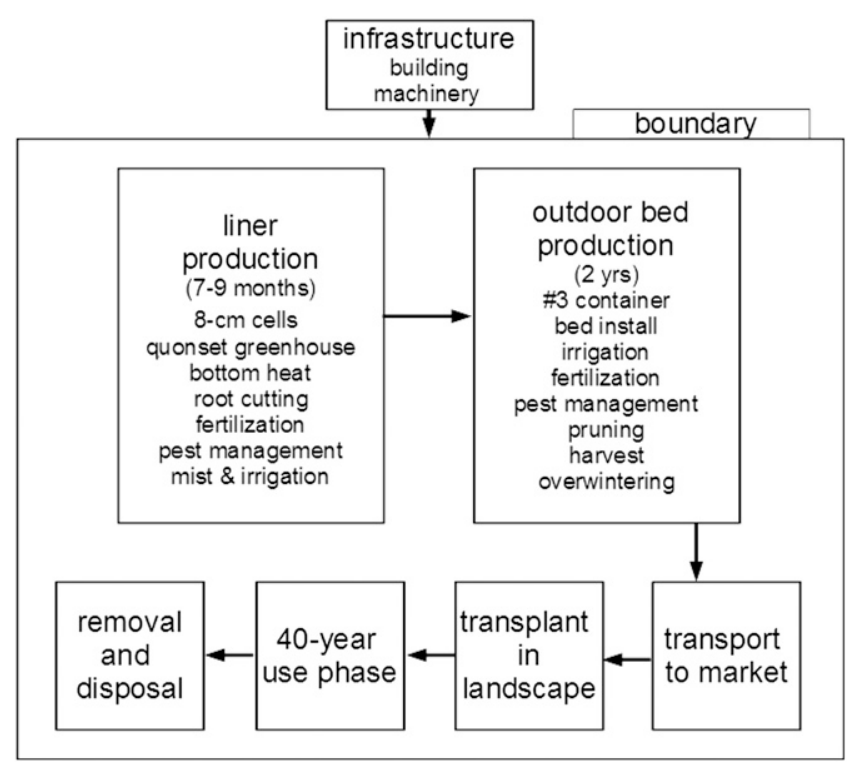

Fig. 1. System diagram and boundaries.

a landscape company, transported to the customer, and transplanted into the landscape. The shrub would reach a size of $1-\mathrm{m}$ high and 1.4-m wide during a 40-year functional life, followed by shrub removal and disposal to compete the life cycle. This LCA study will focus on the GWP and variable costs of production system components.

LCA standards were followed, including the International Organization for Standardization (ISO, 2006) and PAS 2050 guidelines by BSI British Standards (2011). Input products, equipment use, and labor were inventoried for the activities in each production phase. GHG were determined, converted to kilograms $\mathrm{CO}_{2} \mathrm{e}$ per functional unit, and summed. Costs of inputs, equipment use, and labor were determined for the model system. Emissions from the manufacturing of capital goods, such as buildings and machinery, were not included in this study as per PAS 2050, Section 6.4.4.

\section{Input materials, labor, and equipment use for greenhouse production of liners}

The substrate would consist of $85 \%$ aged pine bark, $15 \%$ perlite, and $5 \%$ peat by volume, amended with $2.3 \mathrm{~kg}$ of dolomitic limestone and $3 \mathrm{~kg}$ of 12-month-release, polymer-coated controlled-release fertilizer (CRF; 15N-3.5P-10.0K) with micronutrients per cubic meter. A paddle mixer with 7.46-kW $(1 \mathrm{hp}=0.746 \mathrm{~kW})$ motor would mix $3 \mathrm{~m}^{3}$ of substrate in $5 \mathrm{~min}$ and require a $48.5-\mathrm{kW}$ tractor with front-end loader and two people for $15 \mathrm{~min}$. The substrate would be conveyed with a $1.5-\mathrm{kW}$ motor from the mixer to containers placed on a wagon, $\approx 3$ min per batch. Flats would be used for four crops and hold 18-count, deep-cell inserts used only for one crop. Plants would be moved by a $17.9-\mathrm{kW}$ tractor and wagon to a $5.2 \times 19.8 \mathrm{~m}$ Quonset structure with galvanized bows, covered with double-layer clear plastic and 50\% shadecloth, 618 flats per greenhouse.
Bottom heat necessary to maintain $21 \mathrm{C}$ substrate temperature would be supplied by circulating water heated by a $15-\mathrm{kWh}$ tankless water heater with a $746-W$ electric circulating pump per house through polyvinylchloride pipe on the fabric-covered gravel surface. Bottom heat was assumed to contribute $48 \%$ of heat necessary to maintain a $21 \mathrm{C}$ air temperature February to May with forced air heaters using propane to provide the remaining heat requirement. The heating requirements and fuel consumption of 122.4 L of propane per crop were determined using Virtual Grower, a calculator for greenhouse heating requirements developed and maintained by the Agricultural Research Service, U.S. Department of Agriculture (2015).

Cuttings would be misted until rooted then irrigated as needed. An average of $0.64 \mathrm{~cm}$ of irrigation was assumed to be applied daily for 32 weeks or $146 \mathrm{~m}^{3}$ per house. Irrigation would be pumped from surface water and chlorine would be injected at $6 \mathrm{mg} / \mathrm{L}$ from sodium hypochloride $(15 \%$ chlorine) to yield 1-2 ppm free chlorine at the nozzle. One full-time employee would control and monitor irrigation of 600,000 liners. Fungicides (pyraclostrobin plus boscalid, mancozeb, hydrogen dioxide plus peroxyacetic acid, and thiophanate-methyl) would be rotated in a weekly spray schedule for 24 weeks, using a 100-gallon sprayer with $3.7-\mathrm{kW}$ gasoline engine pulled by a $17.9-\mathrm{kW}$ tractor. One person would invest an average of $3 \mathrm{~min}$ per house per spray. The rooting cuttings would also receive three drenches with mefenoxam plus thiophanatemethyl using a 600-gallon sprayer with 5-kW gasoline engine pulled with the $17.9-\mathrm{kW}$ tractor and require $10 \mathrm{~min}$ with one person per greenhouse. Shrinkage for the propagation phase was assumed to be $10 \%$. Liners would be pruned twice with a gasoline-powered shearer requiring a total of $1 \mathrm{~h}$ per house.
Energy required for overhead (electricity for general activities and gasoline for field truck and ATV) for the liner production phase was calculated from the consumption of electricity at $73 \mathrm{kWh} \cdot \mathrm{ha}^{-1}$ and gasoline at $76 \mathrm{~L} \cdot \mathrm{ha}^{-1}$ as previously published (Hall and Ingram, 2015; Ingram and Hall, 2014a).

\section{Input materials, labor, and equipment use for production in no. 3 container}

The $21.7 \times 73.2-\mathrm{m}$ outdoor beds would be covered with $134 \times 10^{5} \mathrm{~kg} \cdot \mathrm{m}^{-3}$ of gravel covered with a woven polypropylene ground cloth $\left(0.14 \mathrm{~g} \cdot \mathrm{cm}^{-2}\right)$. Gravel was assumed to be transported $40 \mathrm{~km}$ and replenished only after 20 years. The ground cloth was assumed to last 15 years. The no. 3 container was assumed to be made using high-density polyethylene (HDPE) in a blow-mold process and weigh $0.158 \mathrm{~kg}$.

The substrate would consist of aged pine bark delivered to the nursery in $41.3-\mathrm{m}^{3}$ loads. Each load would require $45 \mathrm{~min}$ of a $56.0-\mathrm{kW}$ loader and $30 \mathrm{~min}$ of a $93.2-\mathrm{kW}$ tumbler/screener to blend $5.97 \mathrm{~kg} \cdot \mathrm{m}^{-3}$ of a 12 to 14 -month CRF $(18 \mathrm{~N}-2.2 \mathrm{P}-7.5 \mathrm{~K})$ with micronutrients and dolomitic limestone $\left(2.97 \mathrm{~kg} \cdot \mathrm{m}^{-3}\right)$ to prepare the substrate for potting. Each cubic meter would fill 91 no. 3 containers. A $7.5-\mathrm{kW}$ electric motor would operate a potting machine requiring a 15-person crew and $317.9-\mathrm{kW}$ tractors and two tracking wagons to pot and transport 12,000 plants to the field in $8 \mathrm{~h}$. Containers would be placed cantight initially, 12,000 per bed until spaced in the spring at 6,000 per bed, requiring $48 \mathrm{~h}$ of labor and $317.9-\mathrm{kW}$ tractors and wagons per 12,000 plant bed. For the second winter, the 6000 plants per bed would be placed container-to-container from November to March (16 man-hours per bed) and covered with $50 \%$ polypropylene shadecloth, assumed to last 10 years, in November and removed in March. Covering a bed of plants would require 1.5 labor hours and uncovering would require $2 \mathrm{~h}$ and $20 \mathrm{~min}$ of a 17.9-kW tractor. Plants would be pruned two times per year using gasoline-powered shearers ( 45 min per bed) and two times using hand pruners (14 labor hours per bed).

A 12- to 14-month CRF with minor elements $(18 \mathrm{~N}-2.2 \mathrm{P}-7.5 \mathrm{~K})$ would be surface applied at potting at $70 \mathrm{~g}$ per container, requiring 5.5 labor hours per bed and reapplied the second year of production. Soluble fertilizer $(10 \mathrm{~N}-0.9 \mathrm{P}-5 \mathrm{~K})$ would be applied through the irrigation system 16 times during each growing season, beginning 6 months after potting.

Based on previous work, $19 \mathrm{~mm}$ of water was assumed to be applied 280 times per year to the bed via overhead irrigation (Warsaw et al., 2009). A 44.8-kW pump would supply $22.7 \mathrm{~m}^{3} \cdot \mathrm{min}^{-1}$ to 10 beds at a time. The amount of applied water per plant would be based on plant population per bed, i.e., plant spacing. Runoff irrigation would be captured for reuse. Warsaw et al. (2009) reported that $60 \%$ of applied water from overhead irrigation to no. 3 containers spaced $45 \mathrm{~cm}$ on-center ran off the bed. Monitoring and controlling irrigation per bed would require $11.25 \mathrm{~h}$ per year. 
Chlorine would be injected at $6 \mathrm{mg} \cdot \mathrm{L}^{-1}$ as described above.

Weed control was assumed to involve four applications of granular herbicides per year, rotating between oxyfluorfen and indaziflam, requiring $10 \mathrm{~min}$ per bed and $5 \mathrm{~min}$ of a $24-\mathrm{kW}$ tractor per application. Hand weeding escapes was assumed to require $6 \mathrm{~h}$ per bed each year.

Spring and fall applications of horticultural oil spray with copper hydroxide $(70 \%)$ at $0.6 \mathrm{~g} \cdot \mathrm{L}^{-1}$ plus one spray in June with a tank mix of mancozeb $\left(1.7 \mathrm{~kg} \cdot \mathrm{ha}^{-1}\right)$ and thiophanatemethyl $\left(1.1 \mathrm{~kg} \cdot \mathrm{ha}^{-1}\right)$ was assumed. A $100-\mathrm{kW}$ tractor with 1900-L air-blast sprayer would be used $0.5 \mathrm{~h}$ per bed per application.

Pulling orders and loading trucks was assumed to take $78 \mathrm{~h}$ of labor and $3 \mathrm{~h}$ of a $17.9-\mathrm{kW}$ tractor with two tracking trailers for each 6000 finished no. 3 container plants. Shrinkage of $5 \%$ was assumed for the outdoor production phase.

\section{Equipment use assumptions}

Estimated tractor power $(1 \mathrm{hp}=0.746 \mathrm{~kW})$ requirements for each function were determined through nursery manager interviews. The portion of maximum tractor throttle and load for each operation was assumed to be loading substrate components in mixer, $48.5 \mathrm{~kW}$ at 0.5 throttle and 0.5 load; transporting plants on wagons, pulling sprayers, and transporting other materials to the field, $17.9-\mathrm{kW}$ tractor at 0.50 throttle and 0.50 load; spreading gravel on field beds, $40-\mathrm{kW}$ tractor at 0.50 throttle and 0.50 load; loading pine bark in tumbler/screener, $55.9-\mathrm{kW}$ loader at 0.85 throttle and 0.85 load; tumbler/screener for substrate preparation, $93.2 \mathrm{~kW}$ at 1.0 throttle and 1.0 load; and air-blast sprayer, $74.6-\mathrm{kW}$ tractor at 0.85 throttle and 0.85 load.

The $3.7-\mathrm{kW}$ gasoline-powered spray was assumed to consume $1.25 \mathrm{~L} \cdot \mathrm{h}^{-1}$. Gasolinepowered shearers were assumed to consume $0.63 \mathrm{~L} \cdot \mathrm{h}^{-1}$. Electric motors were assumed to use $0.746 \mathrm{~kW} \cdot \mathrm{hp}^{-1}$. Energy required for overhead for the container production phase was calculated on an area basis as described above.

\section{Labor inputs}

The model included labor requirements for each operation through nursery manager interviews conducted in 2015, with follow-up Delphi-method (Hsu and Sandford, 2007) discussions. Labor requirements for operating equipment were calculated as 1.25 times the equipment operation hours to account for preparation and cleanup time. Labor contributes significantly to costs but does not contribute directly to the GWP of the product.

\section{Postharvest activity assumptions}

A 1500-plant load was assumed to be transported $362 \mathrm{~km}$ by commercial carrier at $\$ 2.48 / \mathrm{km}$. A $32-\mathrm{km}, 30-\mathrm{min}$ trip with a 50-plant load was assumed for the landscaper and 0.5 labor hours (Fortier, 2014) would be required to plant the shrub into the landscape. Following 40 years of useful life in the landscape, shrub removal would require $0.5 \mathrm{~h}$ of labor and $15 \mathrm{~min}$ of a 10-plant load in a pickup truck. This was also compared with shredding on site and composting for mulch, requiring $3 \mathrm{~min}$ of a gasoline shredder using $1.9 \mathrm{~L} \cdot \mathrm{h}^{-1}$.

Cost calculations. Variable costs were estimated using an economic engineering approach for production system components defined through the life cycle inventory (LCI). Fixed costs associated with buildings, land, and general overhead are highly variable between nurseries in the industry and were not included in this analysis, but range from $48 \%$ to $52 \%$ of total costs. The Adverse Effect Wage Rate as determined by the U.S. Department of Labor (2015) for the states included in the lower midwest region was used to set the wage rate of $\$ 11.67$. This represents the wage level that must be offered and paid to migrant workers by agricultural employers of nonimmigrant $\mathrm{H}-2 \mathrm{~A}$ agricultural workers. This wage also tends to act as a floor for nonmigrant wage levels as well. Costs of input materials were obtained from nursery industry wholesale distributors and manufacturers in 2014. Equipment costs per hour were representative of those reported in enterprise budgets for horticultural crops produced in the lower midwest region. The gasoline price of $\$ 0.858 / \mathrm{L}$ represented the U.S. average as reported by the U.S. Energy Information Administration (2015).

\section{Inventory analysis and data collection}

The GWP of inputs was taken from a variety of published sources as follows. The GWP for gasoline and diesel consumption was determined based on "well-to-wheel" emission reported in GREET1_2011 (Vyas and Singh, 2011) as 2.9339 and $3.0153 \mathrm{~kg} \mathrm{CO}_{2} \mathrm{e} / \mathrm{L}$, respectively. The GWP of fluids used by tractors and trucks were calculated using GREET2_7 (Burnham et al., 2006) as previously reported (Ingram, 2013). Fuel consumption was used to determine the GWP of machinery and truck use for each operation. Heavy and light truck diesel consumptions were based on 2.5 and $4.2 \mathrm{~km} \cdot \mathrm{L}^{-1}$ (6 and $10 \mathrm{mpg}$ ), respectively. Published standards for diesel consumption by tractor horsepower, throttle, and load (Grisso et al., 2010) were used for each operation as previously reported (Hall and Ingram, 2014, 2015; Ingram, 2012, 2013; Ingram and Hall, 2013, 2014a, 2014b, 2015a).

GWP of $3.2,1.0$, and $0.7 \mathrm{~kg} \mathrm{CO}_{2} \mathrm{e} / \mathrm{kg}$ for $\mathrm{N}$ from urea, $\mathrm{P}_{2} \mathrm{O}_{5}$, and $\mathrm{K}_{2} \mathrm{O}$ fertilizers, respectively, were assumed as previously published (Snyder et al., 2009; Wang, 2007). U.S. LCI data (U.S. Department of Energy, 2015) and SimaPro (Pre' North America, Inc., Washington, DC) were used to calculate a GWP of input products, including manufacturing processes and transportation. Information on the amount of polymer or the processing of coating fertilizers is not available for proprietary products. Therefore, we assumed the polymer was $10 \%$ of the weight of the input product and the processing energy use was equivalent to polyol, a precursor to polyurethane, and blow-mold processing calculated from manufacturing data in SimaPro, to yield a coating GWP of $0.065 \mathrm{~kg} \mathrm{CO}_{2} \mathrm{e} / \mathrm{kg}$ of fertilizer. This is likely an overestimate of the GWP. A $1 \%$ loss of applied $\mathrm{N}$ as $\mathrm{N}_{2} \mathrm{O}$ was assumed, which would result in an estimated GWP of $4.65 \mathrm{~kg} \mathrm{CO} \mathrm{CO}_{2} \mathrm{e} / \mathrm{kg}$ of $\mathrm{N}$ applied (IPCC, 2006; Snyder et al., 2009; West and Marland, 2003). However, this assumption may not apply directly when using polymercoated $\mathrm{N}$ and could overestimate the potential $\mathrm{N}_{2} \mathrm{O}$ loss impact. The GWP of micronutrients as constituents of fertilizer product was assumed to be insignificant and not included. The average $\mathrm{CO}_{2} \mathrm{e}$ emission for a range of herbicides $(23.083 \mathrm{~kg} \mathrm{CO} 2 \mathrm{e} / \mathrm{kg})$ and limestone $\left(0.5862 \mathrm{~kg} \mathrm{CO} \mathrm{CO}_{2} \mathrm{e} / \mathrm{kg}\right)$ were calculated from data presented by Lal (2004).

The pine bark substrate for the containerproduction phase and the propagation substrate GWP was calculated to be $0.115 \mathrm{~kg}$ $\mathrm{CO}_{2} \mathrm{e} / \mathrm{kg}$, assuming the bark was sourced from a saw mill in the southeastern United States $\left(0.0674 \mathrm{~kg} \mathrm{CO}_{2} \mathrm{e} / \mathrm{kg}\right)$ and transported by tractor/trailer $500 \mathrm{~km}\left(0.0474 \mathrm{~kg} \mathrm{CO}_{2} \mathrm{e} /\right.$ $\mathrm{kg})$. The pine bark would also be processed by a tumbler/screener that added $0.00957 \mathrm{~kg}$ $\mathrm{CO}_{2} \mathrm{e} / \mathrm{kg}$. The propagation substrate GWP was calculated to be $0.145 \mathrm{~kg} \mathrm{CO} C_{2} \mathrm{e} / \mathrm{kg}$, of which $0.104 \mathrm{~kg} \mathrm{CO}_{2} \mathrm{e}$ was from pine bark $(0.83 \mathrm{~kg}), 0.018 \mathrm{~kg} \mathrm{CO}_{2} \mathrm{e}$ was from perlite $(0.15 \mathrm{~kg})$, and $0.023 \mathrm{~kg} \mathrm{CO}_{2} \mathrm{e}$ was from peat $(0.02 \mathrm{~kg})$. The GWP of peat was based on a German model adjusted for U.S. energy by Ecoinvent database (Ecoinvent Center, 2015) accessed through SimaPro.

A GWP of $2.25 \mathrm{~kg} \mathrm{CO} 2 \mathrm{e} / \mathrm{kg}$ for no. 3 containers assumed manufacturing from $100 \%$ recycled HDPE pellets using blow-mold processing, the products being transported $200 \mathrm{~km}$ and $50 \%$ of used containers would be sent to a landfill. A GWP of the propagation trays and inserts manufactured from polystyrene using a blow-mold technology was calculated to be $2.601 \mathrm{~kg} \mathrm{CO} \mathrm{CO}_{2} \mathrm{e} / \mathrm{kg}$, assuming a transported distance of $200 \mathrm{~km}$ and landfill disposal of used material. Polypropylene tubing manufactured from low-density polypropylene using pipe extrusion technology and woven polypropylene fabric from granules and extrusion into sheets and including transport of materials and disposal in landfill was calculated as 2.81 and $2.77 \mathrm{~kg} \mathrm{CO}_{2} \mathrm{e} / \mathrm{kg}$, respectively.

Sensitivity analysis was conducted to evaluate the relative impact of input variable errors as well as the impact of each input variable on the total $\mathrm{kg} \mathrm{CO}_{2} \mathrm{e}$ investment in the shrub. Each input variable within each life phase was in turn increased by $10 \%$, whereas other variables were unchanged in model simulations. The maximum percentage change in total $\mathrm{kg} \mathrm{CO}_{2} \mathrm{e}$ investment in the shrub was used to assess the sensitivity of the model to each variable. The sensitivity of $\mathrm{CO}_{2}$ sequestration during production, use, and end-of-life phases was calculated separately using the same procedures. Sensitivity for each phase was expressed relative to the final carbon footprint. A Monte Carlo analysis with 1000 iterations was also employed using SimaPro to estimate the variability of the calculated GWP of this product.

The impact on atmospheric $\mathrm{CO}_{2}$ as previously published for shrubs using PAS 2050 
protocols (BSI British Standards, 2011). Carbon sequestration during production was determined from the average dry weight of three no. 3 Ilex crenata 'Bennett's Compacta' $(1.03 \mathrm{~kg})$ and the accumulated dry weight during the plant's 40-year life, weighed over a 100-year assessment period, was calculated to be $9.78 \mathrm{~kg}$ using methods previously published (Hall and Ingram, 2014, 2015; Ingram and Hall, 2014a, 2014b).

\section{Results and Discussion}

GHG from input products, cultural practices, and other processes during the production (cutting-to-gate) of an evergreen shrub in a no. 3 container on the east coast of the United States were estimated to be $2.918 \mathrm{~kg}$ $\mathrm{CO}_{2}$ e. Carbon sequestration in the wood of this plant during production, weighted over a 100-year assessment period, would result in a positive impact of $-0.774 \mathrm{~kg} \mathrm{CO}_{2}$ on atmospheric carbon. The resulting carbon footprint for this model system at the nursery gate would be $2.144 \mathrm{~kg} \mathrm{CO}_{2} \mathrm{e}$. This value was significantly smaller than for field-grown trees (6.6 to $12.8 \mathrm{~kg} \mathrm{CO}_{2} \mathrm{e}$ ) and somewhat larger than for field-grown shrubs $(0.70$ to $0.77 \mathrm{~kg}$ $\mathrm{CO}_{2}$ e) (Hall and Ingram, 2015; Ingram, 2012; Ingram and Hall, 2013, 2014a).

The liner produced in the $80-\mathrm{mm}$ container contributed $0.455 \mathrm{~kg} \mathrm{CO} \mathrm{CO}_{2} \mathrm{e}$ to the carbon footprint of the finished plant, after considering a $5 \%$ loss during production in the no. 3 container. Greenhouse heating and bottom heating for the propagation trays contributed $84 \%\left(0.362 \mathrm{~kg} \mathrm{CO}_{2} \mathrm{e}\right)$ of the GHG during liner production. Mist and irrigation, the propagation tray and insert, and the temporary greenhouse structure contributed $7 \%, 5 \%$, and $3 \%$ of liner production GWP, respectively. All other processes and inputs had minimal contributions to GWP of the liner.

GHG attributed to materials during the production of the finished plant in the no. 3 container in this model was $2.328 \mathrm{~kg} \mathrm{CO}_{2} \mathrm{e}$ while equipment use contributed only $0.546 \mathrm{~kg} \mathrm{CO}_{2} \mathrm{e}$ (Table 1). Major contributors to emissions due to materials would include fertilizers $\left(0.687 \mathrm{~kg} \mathrm{CO} \mathrm{CO}_{2} \mathrm{e}\right)$, the container $\left(0.468 \mathrm{~kg} \mathrm{CO} \mathrm{CO}_{2} \mathrm{e}\right)$, the pine bark $(0.211 \mathrm{~kg}$ $\left.\mathrm{CO}_{2} \mathrm{e}\right)$, the gravel surface and ground cloth $\left(0.222 \mathrm{~kg} \mathrm{CO} \mathrm{CO}_{2} \mathrm{e}\right)$, and herbicides $(0.121 \mathrm{~kg}$ $\mathrm{CO}_{2} \mathrm{e}$ ) and account for $74 \%$ of the GHG from material inputs. The most equipment use, although minor, was for applying pesticides, spacing containers, and preparing the substrate and transplanting the liners. The impact of equipment use was shown to be the predominant contributor to the GWP of fieldgrown trees (Ingram, 2012, 2013; Ingram and Hall, 2013) and shrubs (Hall and Ingram, 2015; Ingram and Hall, 2014a). Overhead energy use accounted for $1.5 \%(0.044 \mathrm{~kg}$ $\mathrm{CO}_{2} \mathrm{e}$ ) of $\mathrm{GHG}$ during production.

When examined from an operations perspective, which combined the impact of material and equipment use, a few operations contributed most of the GHG during production (Fig. 2). Fertilization $(0.707 \mathrm{~kg}$ $\left.\mathrm{CO}_{2} \mathrm{e}\right)$, the liner and transplanting $(0.461 \mathrm{~kg}$ $\left.\mathrm{CO}_{2} \mathrm{e}\right)$, the container $\left(0.468 \mathrm{~kg} \mathrm{CO}_{2} \mathrm{e}\right)$, gravel and ground cloth installation $\left(0.222 \mathrm{~kg} \mathrm{CO}_{2} \mathrm{e}\right)$, substrate materials and preparation $(0.227 \mathrm{~kg}$ $\left.\mathrm{CO}_{2} \mathrm{e}\right)$, and weed control $\left(0.122 \mathrm{~kg} \mathrm{CO}_{2} \mathrm{e}\right)$ accounted for $76 \%$ of the GHG.

Contribution of postharvest activities on GWP reflected equipment use $(0.833 \mathrm{~kg}$ $\mathrm{CO}_{2} \mathrm{e}$ ). Transporting the shrub $362 \mathrm{~km}$ to the landscaping company, transporting $32 \mathrm{~km}$ to the landscape site, and transplanting would result in GHG of $0.376,0.458$, and $0 \mathrm{~kg} \mathrm{CO}_{2} \mathrm{e}$, respectively. As expected due to differences in product size and weight and the number of plants per load, the propagation-to-landscape carbon footprint for this container-grown plant $\left(2.337 \mathrm{~kg} \mathrm{CO}_{2} \mathrm{e}\right)$ is much smaller than for the larger field-grown trees (8.2 to $13.7 \mathrm{~kg} \mathrm{CO}_{2} \mathrm{e}$ ) and shrubs ( 3.16 and $3.22 \mathrm{~kg} \mathrm{CO}_{2} \mathrm{e}$ ) referenced above. Postharvest activities for a $5-\mathrm{cm}$ caliper red maple tree from a field production system contributed $72 \%$ more than that tree produced in the pot-in-pot system due to its lower weight and more trees per load (Ingram and Hall, 2016).

Removal from the landscape and disposal at the end of life contributed $0.115 \mathrm{~kg} \mathrm{CO}_{2} \mathrm{e}$ to the life cycle of this shrub. All of that was from use of a pickup truck. If the shrub was shredded on site with a gasoline-powered shredder, the activities at the end of life would have been $0.092 \mathrm{~kg} \mathrm{CO}_{2} \mathrm{e}$.

Although the life of a plant in the landscape can vary greatly due to planting site, human activities, and maintenance requirements, estimating the impact of the plant during its useful life in the landscape and disposal of the plant at the end of its life is necessary for a life cycle view of the product. The accumulated, weighted impact of annual sequestration of carbon by this shrub over its 40 -year life was calculated to be $-4.537 \mathrm{~kg} \mathrm{CO}_{2}$. When summing the positive and negative impacts of the complete life cycle of this evergreen shrub, the life cycle GWP was estimated to be $-1.445 \mathrm{~kg}$ $\mathrm{CO}_{2} \mathrm{e}$. This value is much smaller than the life cycle GWPs of $-800,-431$, and $-63 \mathrm{~kg}$ $\mathrm{CO}_{2} \mathrm{e}$ previously published and updated for field-grown, 5-cm-caliper red maple (Ingram, 2012), blue spruce (Ingram, 2013), and redbud (Ingram and Hall, 2013) trees, as well as the -11.3 and $-8.2 \mathrm{~kg} \mathrm{CO} \mathrm{CO}_{2} \mathrm{e}$ for field-grown viburnum (Ingram and Hall, 2014a) and yew (Hall and Ingram, 2015) shrubs, which reach a larger mature size than the holly in this study.

Seldom do LCA studies include system component costs; however, detailed production protocols include the majority of cost contributors except for labor. By adding labor to the LCI development phase of the study and assigning a cost to materials and equipment use from published sources, total variable costs can be determined for each operation and related to GWP. In this study and previous studies (Hall and Ingram, 2015; Ingram and Hall, 2013, 2014a), the major contributors to GWP were also major contributors to the variable costs except for processes that required significant labor investments (Table 1) rather than materials and/or equipment usage.

Liner production costs contributed $\$ 0.292$ to the total variable costs of the finished no. 3 shrub, considering 5\% shrinkage. Labor was

Table 1. Contribution of individual production system components on global warming potential (GWP) and variable costs (\$) for an evergreen shrub, such as Ilex crenata 'Bennett's Compacta', in a no. 3 container grown in an east coast U.S. nursery.

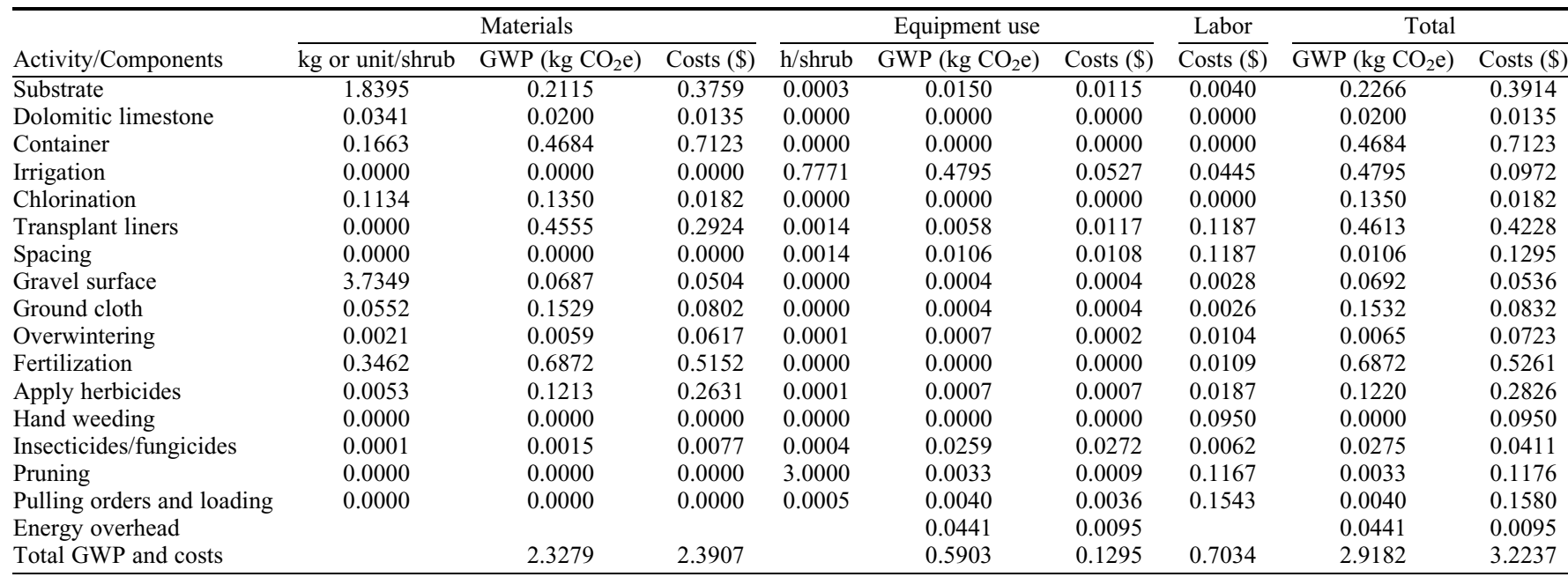


$46 \%$ of total variable costs during liner production (\$0.278), followed in importance by materials (37\%) and equipment (17\%).

The variable costs from cutting to gate totaled \$3.224. During outdoor production of the finished shrub in a no. 3 container, materials comprised $74 \%$ of total variable costs, followed by labor (22\%) and equipment (4\%) (Table 1). Operations (and associated inputs) identified as contributing most to the variable costs at the farm gate included the container $(22 \%)$, followed by fertilization $(16 \%)$, substrate materials and preparation $(12 \%)$, the liner $(13 \%)$, and weed control (12\%) (Fig. 3). Cost of overwintering and spacing $(6 \%)$, labor for pulling orders and loading trucks $(5 \%)$, and gravel and ground cloth $(4 \%)$ were of secondary importance. Insecticide applications, overhead energy, irrigation, and pruning had the least impact on total variable costs. Variable costs for postharvest activities, including transport and transplanting, totaled to $\$ 6.409$ per shrub and were dominated by labor costs $(90 \%)$.

The sensitivity analysis for GWP revealed at least a $1 \%$ increase in total GHG with a $10 \%$ increase in five of the 28 operational variables and for variable costs in four of those five operations in the production phase. Assessed from cutting to gate, a 10\% increase in the GWP of the fertilization, container, irrigation, and liner had more than a $1 \%$ impact on total GHG. The same was true for variable costs except for irrigation, which accounted for $3 \%$ of total variable costs but $16 \%$ of GWP. The Monte Carlo analysis of the GWP production protocols revealed a standard deviation of $0.161 \mathrm{~kg} \mathrm{CO} \mathrm{C}$ at the $95 \%$ probability level, revealing a relatively high confidence in the overall assessment.

Models such as the one developed in this LCA study can be used as important tools to address questions about impact of potential operation modifications on GWP and cost. For example, if fertilizer use could be reduced by $10 \%$, the cutting-to-gate GWP would be reduced by $0.0687 \mathrm{~kg} \mathrm{CO}_{2} \mathrm{e}$ or $3 \%$ to $2.076 \mathrm{~kg} \mathrm{CO} \mathrm{CO}_{2} \mathrm{e}$ and save $\$ 0.052$. If the process for container manufacturing could reduce the GWP of the no. 3 container by $10 \%$, the cutting-to-gate GWP would be reduced by only $0.047 \mathrm{~kg} \mathrm{CO}_{2} \mathrm{e}$ or $2.2 \%$ to $2.098 \mathrm{~kg} \mathrm{CO}_{2} \mathrm{e}$. Reducing the GWP of several operations in the production model, including irrigation, pulling orders, and loading trucks, would have negligible impact on the cuttingto-gate GWP.

If only $75 \%$ of the plants sold in the fall and $25 \%$ were maintained for six additional months and sold in the spring, $0.653 \mathrm{~kg}$ $\mathrm{CO}_{2} \mathrm{e}$ GHG and $\$ 0.478$ in variable costs would be added to each of those carried-over plants. However, if those GHG were spread across the total plants sold, the increase would be $0.163 \mathrm{~kg}$ $\mathrm{CO}_{2} \mathrm{e}(5.6 \%)$ and $\$ 0.120$ per plant $(3.7 \%)$.

\section{Conclusions}

Analysis of nursery crop production systems using LCA has resulted in a greater understanding of the major contributing

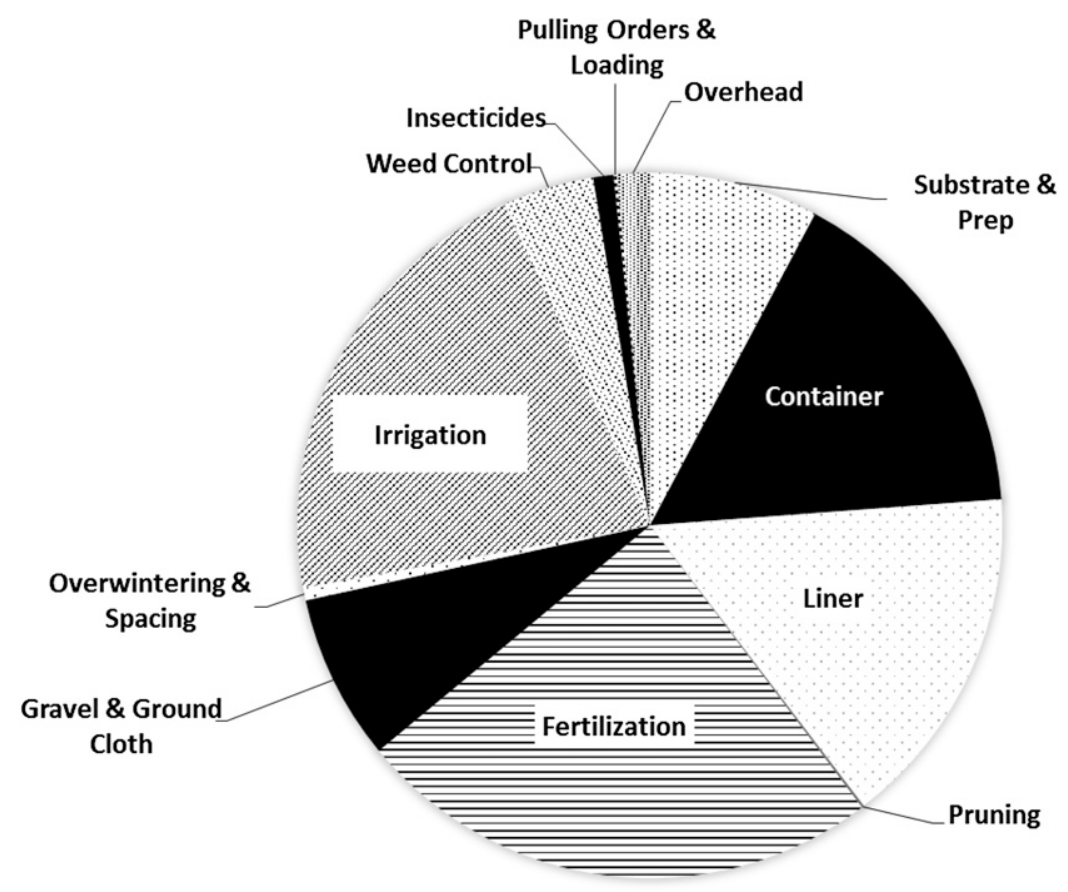

Fig. 2. The impact on global warming potential of greenhouse gas emissions during the production system components (materials, equipment use, and energy overhead) for a broadleaf evergreen shrub, such as Ilex crenata 'Bennett's Compacta', in a no. 3 container in an east coast U.S. nursery.

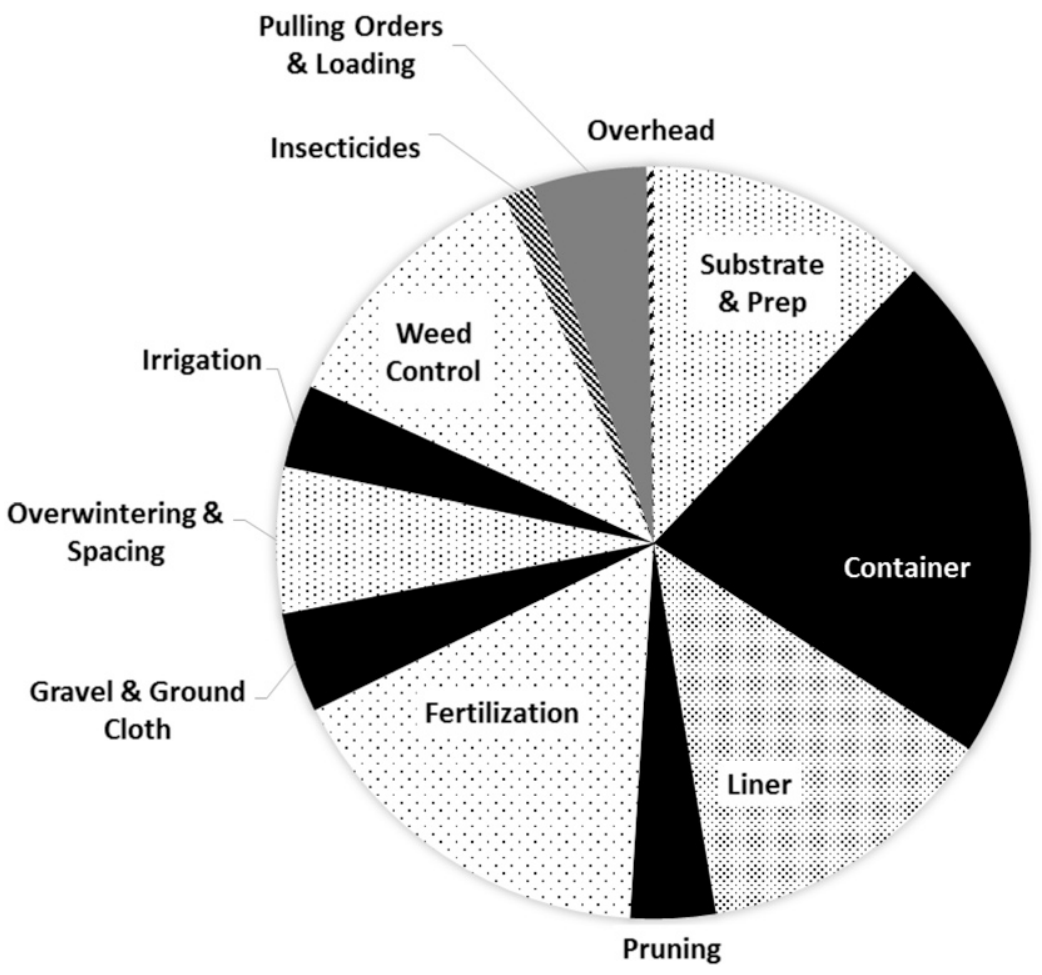

Fig. 3. Variable costs of production system components (material, equipment use, and labor) for a broadleaf evergreen shrub, such as Ilex crenata 'Bennett's Compacta', in a no. 3 container in an east coast U.S. nursery.

factors to GWP and variable costs. The cutting-to-gate GWP of a container-grown evergreen shrub was estimated to be less than the accumulated, weighted impact of annual carbon sequestration. Such information will inform nursery managers and equip them for making better decisions on production protocols, market area, and ways to communicate the economic and environmental value of their products to the consuming public. 


\section{Literature Cited}

Beccaro, G.L., A.K. Cerutti, I. Vandecasteele, L. Bonvegna, D. Donno, and G. Bounous. 2014 Assessing environmental impacts of nursery production: Methodological issues and results from a case study in Italy. J. Clean. Prod. 80:159-169.

BSI British Standards. 2011. Specification for the assessment of the life cycle greenhouse gas emissions of goods and services. BSI British Standards (Publicly Available Specification) PAS 2050:2011.

Burnham, A., M. Wang, and Y. Wu. 2006. Development and applications of GREET 2.7-The transportation vehicle-cycle model. ANL/ESD/ 06-5. 13 Nov. 2015. <http://www.transportation. anl.gov/pdfs/TA/378.PDF>.

Davis, S.C., K.J. Anderson-Teixeira, and E.H Dulucia. 2009. Life-cycle analysis and the ecology of biofuels. Trends Plant Sci. 14(3):140-146.

Debolt, S., J.E. Campbell, R. Smith, M. Montross, and J. Stork. 2009. Life cycle assessment of native plants and marginal lands for bioenergy agriculture in Kentucky as a model for south-eastern USA. GCB Bioenergy 1(4): 308-316.

Farrell, A.E., R.J. Plevin, B.T. Turner, A.D. Jones, M. O'Hare, and M. Kammon. 2006. Ethanol can contribute to energy and environmental goals. Science 311(5760):506-508.

Fortier, B. (ed.). 2014. RSMeans site work and landscape cost data. 37th annual edition. R.S. Means Company, Norwell, MA.

Ecoinvent Centre. 2015. Ecoinvent 3.0. Competence Centre of the Swiss Federal Institute of Technology, Zurich, Switzerland. 17 July 2015. $<$ http://www.ecoinvent.org/database/>.

Grisso, R., J. Perumpral, D. Vaughan, G. Roberson, and P. Pitman. 2010. Predicting tractor diesel fuel consumption. Va. Coop. Ext. Pub. 442-073.

Hall, C.R. 2010. Making cents of green industry economics. HortTechnology 20:832-835.

Hall, C.R. and D.L. Ingram. 2014. Production costs of field-grown Cercis canadensis L. 'Forest Pansy' identified during life cycle assessment analysis. HortScience 49:1-6.

Hall, C.R. and D.L. Ingram. 2015. Carbon footprint and production costs associated with varying the intensity of production practices during field-grown shrub production. HortScience 50:402-407.

Hayashi, K., G. Gaillard, and T. Nemecek. 2006. Life cycle assessment of agricultural production systems: Current issues and future perspectives. International Seminar on Technology Development for Good Agricultural Practice in Asia and Oceania, Taipei, Taiwan. Food and Fertilizer Technology Center. p. 98-110.

Hsu, C.C. and B. Sandford. 2007. The Delphi technique: Making sense of consensus. Pract. Assess. Res. Eval. 12(10):1-7.
Ingram, D.L. 2012. Life cycle assessment of a fieldgrown red maple tree to estimate its carbon footprint components. Intl. J. Life Cycle Assess. 17(4):453-462.

Ingram, D.L. 2013. Life cycle assessment to study the carbon footprint of system components for Colorado blue spruce field production and landscape use. J. Amer. Soc. Hort. Sci. 138:3-11.

Ingram, D.L. and C.R. Hall. 2013. Carbon footprint and related production costs of system components of a field-grown Cercis canadensis L. 'Forest Pansy' using life cycle assessment. J. Environ. Hort. 31(3):169-176.

Ingram, D.L. and C.R. Hall. 2014a. Carbon footprint and related production costs of system components for a field-grown Viburnum $\times j u d d i$ using life cycle assessment. J. Environ. Hort. 32:175-181.

Ingram, D.L. and C.R. Hall. 2014b. Life cycle assessment used to determine the potential environment impact factors and water footprint of field-grown tree production inputs and processes. J. Amer. Soc. Hort. Sci. 140:1021-1107.

Ingram, D.L. and C.R. Hall. 2015a. Carbon footprint and related production costs of pot-in-pot system components for red maple using life cycle assessment. J. Environ. Hort. 33(3):103-109.

Ingram, D.L. and C.R. Hall. 2015b. Using life cycle assessment (LCA) to determine the carbon footprint of trees during production, distribution and useful life as the basis for market differentiation. In: Proc. 1st International Symposium on Horticulture Economics, Marketing and Consumer Research. Acta Hort. 1090:35-38.

Ingram, D.L. and C.R. Hall. 2016. Comparison of carbon footprint and variable costs of selected nursery production systems for a 5-cm-caliper red maple. HortScience 51:383-386.

Intergovernmental Panel on Climate Change (IPCC). 2006. Guidelines for national greenhouse gas inventories. Volume 4: Agriculture, forestry and other land use. Chapter 11: $\mathrm{N}_{2} \mathrm{O}$ emissions from managed soils, and $\mathrm{CO}_{2}$ emissions from lime and urea application. 13 Nov. 2015. <http://www. ipcc-nggip.iges.or.jp/public/2006gl/vol4.html > .

International Organization for Standardization (ISO). 2006. Life cycle assessment, requirements and guidelines. ISO Rule 14044:2006. Intl. Organization for Standardization, Geneva, Switzerland.

Kendall, A. and E.G. McPherson. 2012. A life cycle greenhouse gas inventory of a tree production system. Intl. J. Life Cycle Assess., doi: 10.1007/s11367-011-0339-x.

Koerber, G.R., G. Edwards-Jones, P.W. Hill, L. Milà i Canals, P. Nyeko, E.H. York, and D.L. Jones. 2009. Geographical variation in carbon dioxide fluxes from soils in agro-ecosystems and its implications for life-cycle assessment. J. Appl. Ecol. 46(2):306-314. (Special profile: Integrating ecology and the social sciences.).

Lal, R. 2004. Carbon emissions from farm operations. Environ. Intl. 30:981-990.
Lazzerini, G., S. Lucchetti, and F.P. Nicese. 2016. Greenhouse gases (GHG) emissions from the ornamental plant nursery industry: A life cycle assessment (LCA) approach in a nursery district in central Italy. J. Clean. Prod. 112(5): 4022-4030.

Liebig, M.A., M.R. Schmer, K.P. Vogel, and R.B. Mitchell. 2008. Soil carbon storage by switchgrass grown for bioenergy. BioEnergy Res. 1(3): 215-222.

Nicese, F.P. and G. Lazzerini. 2013. CO2 sources and sink in ornamental plant nurseries. Acta Hort. 90:91-98.

Payraudeau, S. and H.M.G. van der Werf. 2005. Environmental impact assessment for a farming region: A review of methods. Agr. Ecosyst. Environ. 107(1):1-19.

Snyder, C.S., T.W. Bruulsema, T.L. Jensen, and P.E. Fixen. 2009. Review of greenhouse gas emissions from crop production systems and fertilizer management effect. Agr. Ecosyst. Environ. 133:247-266.

Southern Nursery Association. 2013. Best management practices: Guide for producing nursery crops. 3rd ed. SNA, Acworth, GA.

U.S. Department of Agriculture, Agricultural Research Service. 2015. Virtual Grower 3 Model. 13 Nov. 2015. <http://ars.usda.gov/Research/ docs.htm?docid $=22087>$.

U.S. Department of Energy. 2015. U. S. Life-cycle inventory database. National Renewable Energy Lab (NREL). 13 Nov. 2015. <https://www. lcacommons.gov/nrel/search $>$.

U.S. Department of Labor. 2015. Wages in agriculture. 13 Nov. 2015. <http://www.dol.gov/ compliance/topics/wages-agricultural.htm $>$.

U.S. Energy Information Administration. 2015. Gasoline and diesel fuel update. 13 Nov. 2015. <www.eia.gov/petroleum/gasdiesel>.

Vyas, A. and M. Singh. 2011. GREET1_2011 (Greenhouse gases, related emissions, and energy use in transportation). Argonne National Laboratory, Chicago, IL. 13 Nov. 2015. <http://www. anl.gov/energy-systems/project/vision-model>

Wang, M.Q. 2007. GREET 1.8a Spreadsheet Model. 13 Nov. 2015. <http://www.transportation. anl.gov/modeling_simulation/index.html $>$.

Warsaw, A.L., R.T. Fernandez, B.M. Cregg, and J.A. Andersen. 2009. Container-grown ornamental plant growth and water runoff nutrient content and volume under four irrigation treatments. HortScience 44:1573-1580.

West, T.O. and G. Marland. 2003. Net carbon flux from agriculture: Carbon emissions, carbon sequestration, crop yield, and land-use change. Biogeochemistry 63(1):73-83.

Yue, C.Y., J.H. Dennis, B.K. Behe, C.R. Hall, B.L. Campbell, and R.G. Lopez. 2011. Investigating consumer preference for organic, local, or sustainable plants. HortScience 46:610-615 